\title{
PENGEMBANGAN MODEL PERHITUNGAN NILAI KESELAMATAN TRANSPORTASI JALAN DENGAN PENDEKATAN ILMU PSIKOLOGI
}

\author{
Pungkas Hendratmoko \\ Politeknik Keselamatan Transportasi Jalan, Tegal, Indonesia.
}

\begin{abstract}
Abstrak
Penelitian ini menitikberatkan tentang pengembangan model perhitungan nilai keselamatan transportasi jalan dengan pendekatan ilmu psikologi. Tujuannya untuk memberikan opini dan kritik tentang model dimaksud. Penelitian dilakukan dengan cara mengulas berbagai pendapat dan data empiris dari model dimaksud. Hasil penelitian menunjukan bahwa pada model perhitungan nilai keselamatan transportasi jalan, preferensinya belum dapat merefleksikan perilaku responden sebenarnya. Kesimpulannya diyakini bahwa model tersebut dapat dikembangkan lebih akurat dengan menyertakan itensi pada model sebagai instrumen kontrol.
\end{abstract}

Kata Kunci : Preferensi, Intensi, nilai keselamatan transportasi jalan

\section{PENDAHULUAN}

Model perhitungan nilai keselamatan transportasi jalan/value of road safety (VRS) biasa digunakan oleh perencana untuk menghitung manfaat/ benefit investasi di bidang keselematan transportasi jalan Di sisi lain penurunan jumlah orang yang terluka, dan tewas di jalan mencerminkan efektivitas investasi di bidang keselamatan transportasi jalan. Investasi tersebut tentunya menyebabkan pengeluaran, oleh karena itu, untuk menilai kelayakan ekonomi investasi dimaksud, perhitungan manfaatnya harus dilakukan dengan benar.

Pendekatan yang paling dominan dan fleksibel untuk menghitung VRS saat ini adalah dengan pendekatan perhitungan kemauan masyarakat untuk membayar/willingness to pay (WTP) dengan metode SP. Dalam kaitannnya dengan hal tersebut, preferensi dijadikan indikator yang merefleksikan perilaku responden untuk membayar dalam upaya menurunkan fatalitas kecelakaan lalu lintas. Hal ini banyak mendapat kritik dari para peneliti yang menyatakan bahwa preferensi bukanlah satu-satunya variabel yang menentukan perilaku manusia, sehingga berpengaruh terhadap validitas hasil analisisnya. Di sisi lain pada salah satu model perilaku dalam ilmu psikologi menjelaskan bahwa variabel yang menentukan perilaku manusia adalah niat/Itensi. 
Tujuan dari penelitian ini adalah untuk memberikan opini tentang model perhitungan VRS yang dilakukan dengan cara mengulas berbagai pendapat dan data empiris dari model dimaksud yang pada akhirnya diharapkan dapat bermanfaat untuk pengembangan ilmu pengetahuan.

\section{KAJIAN TEORI}

Model perhitungan VRS dengan pendekatan WTP berkeselamatan dilakukan dengan mengacu pada model teoritis nilai hidup statistik/value of stastical life (VoSL).

Selanjutnya perhitungan WTP dilakukan dengan metode menilai preferensi, yaitu dengan cara menanyakan langsung kepada responden tentang kesediaanya membayar untuk menurunkan jumlah fatalitas kecelakaan lalu lintas. Nilai preferensi tersebut didefinisikan sebagai jumlah maksimum yang bersedia dibayarkan oleh setiap responden dalam upaya meningkatkan keselamatan atau untuk mengurangi jumlah fatalitas kecelakaan lalu lintas. Pada penelitian ini selanjutnya disebut sebagai nilai preferensi berkeselamatan.

\subsection{Model Teoritis Nilai Hidup Statistik / value of stastical life (VoSL)}

Model Teoritis nilai hidup statistik/value of statistikal life (VoSL) adalah model yang menjelaskan tentang nilai rata-rata dari tingkat subtitusi marginal/marginal rate of subtitution (MRS) antara biaya keselamatan dengan penurunan jumlah kecelakaan fatal lalu lintas (Andersson, 2013). Model ini diadopsi dari teori ekonomi mikro. Pada model ini yang dimaksud dengan biaya keselamatan adalah kesediaan individu untuk membayar (WTP) dalam upaya peningkatan keselamatan transportasi jalan, sedangkan yang dimaksud dengan penurunan jumlah kecelakaan fatal lalu lintas adalah kondisi yang dirancang/hipotetis pada survei SP tentang penurunan jumlah korban jiwa akibat kecelakaan fatal lalu lintas. Pada model VoSL, WTP adalah pertukaran /trade-off antara uang dengan penurunan jumlah kecelakaan fatal lalu lintas.

Landasan teori VoSL berasal dari suatu konsep preferensi yang di rancang pada kondisi hipotetis. Oleh karena itu metode pengukuran preferensi yang paling tepat digunakan pada model VoSL adalah metode stated preference (SP). Pada metode SP setiap individu cenderung untuk memaksimalkan preferensinya/nilai utilitasnya (Jones lee, 1974; Rosen,1988).

$\operatorname{VoSL}=\frac{\Delta \mathrm{W}}{\Delta \mathbf{P}}$ 
Persamaan (2.1), adalah prakiraan dari nilai marginal WTP $(\Delta \mathrm{W})$ terhadap penurunan resiko kecelakaan $(\Delta \mathrm{P})$, dimana nilainya harus sebanding, dan proporsional.

Ketika meneliti perilaku berkeselamatan, sebenarnya kita sedang mempelajari pilihan diskrit, dimana setiap individu akan menggunakan alat pengaman hanya jika manfaat menggunakan alat tersebut lebih besar daripada biayanya.

\subsection{Perilaku dari Prespektif IImu Ekonomi}

Persoalan penting yang menjadi fokus perhatian ilmu ekonomi ialah kelangkaan (scarcity), untuk memecahkan masalah tersebut, dilakukan alokasi terhadap pilihan yang menimbulkan kepuasan (utility) tertinggi bagi seorang individu.

Dalam menentukan pilihan, manusia diasumsikan sebagai homo economicus yang paling mengetahui keinginannya dengan prinsip yang dikenal dengan rasionalitas ekonomi.

Ilmu ekonomi mikro (sering juga ditulis mikro ekonomi) adalah cabang dari ilmu ekonomi yang mempelajari perilaku konsumen. Tujuan konsumen mengkonsumsi barang adalah untuk memperoleh manfaat atau kepuasan sebesar-besarnya dari barang yang dikonsumsi (maximum satisfaction). Teori ekonomi menganggap bahwa maximum satisfaction itu adalah tujuan akhir konsumen.

Menurut Pyndyck dkk. (2001), untuk mengetahui perilaku konsumen salah satunya dapat dipahami dari preferensi konsumen, ini adalah langkah pertama untuk menjelaskan alasan seseorang yang lebih suka suatu jenis produk daripada jenis produk yang lain.

Ben Akiva, dan Lerman (1985) mengusulkan suatu kerangka berpikir mengenai proses memilih. Proses memilih pertama-tama diawali dengan menentukan alternatif pilihan, kemudian dilanjutkan dengan mengevaluasi atribut-atribut yang ada pada masing-masing alternatif. Setelah itu menentukan aturan yang akan digunakan untuk memilih salah satu diantara alternatif-alternatif yang ada.

Sejalan dengan kerangka berpikir di atas, dalam model ekonomi rasional, perilaku konsumen dalam menetapkan pola pilihannya menggunakan konsep preferensi, bahwa jika seseorang lebih menyukai barang $\mathrm{X}$ daripada $\mathrm{Y}$, berarti dalam segala kondisi, $\mathrm{X}$ lebih disukai daripada Y. 
Preferensi manusia diasumsikan mengikuti pola tersebut, sehingga alternatif-alternatif yang tersedia dapat disusun berdasarkan ranking mulai paling disukai hingga paling tidak disukai, dimana masing-masing alternatif tersebut dinyatakan berdasarkan nilai utilitasnya. Preferensi manusia adalah fungsi dari utilitas, utilitas adalah indikator dari nilai kepuasan/kegunaan yang dirasakan oleh konsumen. Besarnya nilai utilitas diperoleh dengan cara menilai atribut-atribut yang ada pada alternatif sedemikian rupa, sehingga utilitas ini merupakan sebuah fungsi matematis dari atribut-atribut yang terdapat dalam alternatif tersebut.

Dalam hubungannya dengan pemilihan alternatif dari serangkaian alternatif yang ada, sebagai mahluk yang rasional, manusia akan selalu berusaha untuk memaksimalkan nilai kepuasaan atau nilai kegunaan dari alternatif tersebut. Konsep utility maximization menyatakan bahwa seseorang akan memilih salah satu alternatif dari serangkaian alternatif yang ada yang akan memaksimalkan utilitasnya. Konsep tersebut menyiratkan bahwa terdapat sebuah fungsi yang memuat atribut-atribut dari serangkaian alternative, dan karakteristik individu-individu yang menjelaskan penilaian utilitas individu dari masing-masing alternatif.

Preferensi bisa didefinisikan sebagai fungsi dari utilitas, dan utilitas bisa didefenisikan sebagai kombinasi linier dari beberapa atribut, dan variabel yang membentuknya, sebagai berikut:

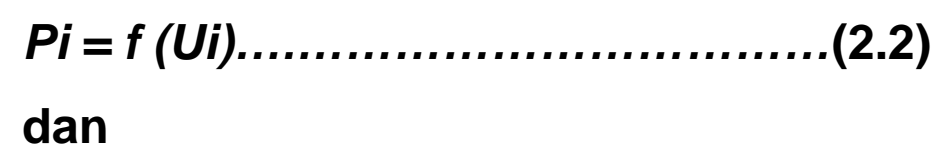

\section{$U_{i}=a_{0}+a_{1} X_{1}+a_{2} X_{2}+\ldots \ldots .+a_{n} X_{n \ldots \ldots . . .}(2.3)$}

yang mana :

$\mathrm{Pi} \quad=$ Preferensi $i$ atau Pilihan $i$

$f($ Ui) $\quad=$ Fungsi Utililitas Pilihan $i$

$U_{i} \quad=$ Utilitas Pilihan $i$

$a_{0}, \ldots, a_{n}=$ Parameter Model

$X_{1}, \ldots, X_{n}=$ Nilai Atribut

Menurut Koppelman, dkk (2006), terdapat tiga sumber kesalahan utama dalam menggunakan fungsi utilitas deterministik, yaitu : 1). Individu tidak memiliki informasi yang lengkap, dan benar tentang serangkaian alternatif yang ditanyakan sehingga terjadi kesalahan persepsi mengenai alternatif dimaksud, 2). Peneliti tidak mempunyai informasi yang lengkap tentang serangkaian alternatif yang disusun, sehingga meninbulkan bias 
terhadap jawaban responden, dan 3). Peneliti tidak dapat mengetahui atau memahami keadaan, atau situasi yang mempengaruhi individu dalam mengambil keputusan.

Jika peneliti benar-benar bisa memahami semua aspek dari proses pengambilan keputusan setiap individu, dan persepsi setiap individu tentang serangkain alternatif yang ditanyakan, maka peneliti dapat menggambarkan perilaku manusia dengan menggunakan model utilitas deterministik

Kenyataan telah menunjukkan lain, bahwa peneliti tidak memiliki pengetahuan tersebut,dan tidak memahami sepenuhnya proses pengambilan keputusan dari masing - masing individu atau persepsi setiap individu mengenai serangkaian alternatif yang ditanyakan. Oleh karena itu, model pemilihan seharusnya mengakomodasi ketidakakuratan informasi, dan memasukkan unsur probabilitas atas ketidakpahanman individu atas serangkaian alternatif yang ditanyakan, sehingga pilihan atas serangkaian alternatif tersebut dinyatakan dalam bentuk probabilitas pilihan. Model utilitas yang mengakomodasi unsur ketidakpastian ini dinamakan model utilitas probabilistik. Sebagaimana pada teori pilihan deterministik, individu diasumsikan memilih sebuah alternatif jika utilitasnya lebih besar dari pada utilitas alternatif lainnya. Fungsi utilitas yang dinilai mengandung dua unsur utama, yaitu : 1). Utilitas yang diperoleh berdasarkan atribut-atribut yang dapat diamati yang ada pada alternatif, dan 2). Unsur yang merupakan selisih antara utilitas yang dapat diprediksi dengan utilitas sebenarnya yang diterima konsumen (Koppelman, dkk., 2006). Selisih antara kedua utilitas ini dinyatakan dalam variabel acak (random variabel) karena utilitas yang sebenarnya yang diterima oleh konsumen tidak dapat diketahui. Utilitas yang memperhitungkan unsur probabilitas tersebut dapat direpresentasikan sebagai berikut:

$$
U_{i t}=V_{i t}+\varepsilon i t
$$

yang mana :

$U_{\text {it }} \quad$ merupakan utilitas yang sebenarnya, dan altematif " $i$ " pada pengambil keputusan " $t$ "

$V_{i t} \quad$ merupakan porsi deterministic, atau porsi yang teramati dari utilitas yang diperkirakan oleh peneliti,

$\varepsilon_{i t} \quad$ adalah error, atau porsi, dan utilitas yang tidak diketahui oleh pengamat.

Dari rumus di atas, dapat dilihat bahwa peneliti tidak memiliki informasi mengenai error. Sehingga total error yang merupakan jumlah error dari banyak sumber (informasi yang tidak 
tepat, kesalahan pengukuran, dan sebagainya) diwakili oleh variabel acak. Perbedaan asumsi mengenai distribusi variabel acak yang berkenaan dengan utilitas, dan masing-masing alternatif menyebabkan perbedaan jenis model yang digunakan untuk menggambarkan, dan memprediksi probabilitas pilihan.

\subsection{Perilaku dari Prespektif Ilmu Psikologi}

Dalam prespektif ilmu psikologi dikenal berbagai teori mengenai perilaku. Teori-teori tersebut masing-masing memiliki dasar pemikiran yang berbeda satu dengan yang lainnya. Secara garis besar terdapat dua buah konsep perilaku yang mendasari pemikiran dari teori-teori tersebut, yaitu : 1). Konsep yang mendasarkan pada perilaku manusia yang bersifat altruistic, yaitu perilaku pro sosial yang lebih mementingkan kepentingan orang lain, atau kepentingan bersama, dan 2). Konsep yang mendasarkan pada nilai utilitas, atau nilai kegunaan pribadi.

Konsep yang mendasarkan pada perilaku manusia yang bersifat altruistic menyatakan bahwa perilaku seseorang dilakukan karena adanya pertimbangan/kewajiban moral dari individu dengan mengutamakan kepentingan orang lain atau kepentingan bersama, dan mengesampingkan kepentingan dirinya sendiri. Konsep perilaku ini hanya dapat diterapkan terhadap individu yang telah memiliki kesadaran yang tinggi bahwa suatu perilaku akan memberikan konsekuensi tertentu untuk mencapai tujuan bersama. Tentu saja konsep ini sangat tidak relevan dengan kondisi dimana kesadaran individu masih sangat rendah.

Berbeda dengan konsep perilaku altruistic, konsep perilaku yang mendasarkan pada nilai utilitas lebih menunjukan perilaku manusia yang rasional dalam menentukan pilihannya. Konsep ini memiliki kesamaan dengan konsep perilaku pada ilmu ekonomi mikro. Yang membedakan hanya pada teori ekonomi mikro perilaku manusia terbentuk atas dasar preferensinya sedangkan pada ilmu psikologi perilaku manusia terbentuk atas dasar sikapnya (attitude). Teori perilaku yang mendasarkan pada sikap (attitude) telah memberikan banyak kontribusi, dan manfaat bagi pemahaman, dan perkembangan teori perilaku di bidang ilmu psikologi, salah satunya adalah teori niat/intensi berperilaku.

Secara khusus teori intensi berperilaku telah dikembangkan oleh Fishben, dan Ajzen. Teori ini yang awalnya dinamai Theory of Reasoned Action (TRA), dikembangkan pada tahun 1967, selanjutnya TRA terus direvisi, dan diperluas oleh Ajzen, dan Fishbein menjadi Theory of Planned Behavior (TPB).

TRA/TPB dimulai dengan melihat intensi berperilaku sebagai variabel terdekat dari suatu perilaku. Diyakini bahwa semakin kuat intensi seseorang untuk menampilkan suatu perilaku 
tertentu, diharapkan semakin berhasil ia melakukannya. Intensi adalah suatu fungsi dari beliefs, dan atau informasi yang penting mengenai kecenderungan bahwa menampilkan suatu perilaku tertentu akan mangarahkan pada suatu hasil yang spesifik. Intensi bisa berubah karena waktu. Semakin lama jarak antara intensi, dan perilaku, semakin besar kecenderungan terjadinya perubahan intensi. Karena Ajzen, dan Fishbein tidak hanya tertarik dalam hal meramalkan perilaku tetapi juga memahaminya, mereka mulai mencoba untuk mengindentifikasi penentu-penentu dari intensi berperilaku. Mereka berteori bahwa intensi adalah suatu fungsi dari dua penentu utama, yaitu 1). sikap terhadap perilaku, dan 2). norma subjektif dari perilaku.

Sikap terhadap perilaku/attitude toaward behavior (ATB), dianggap sebagai variabel pertama dari intensi perilaku. Sikap adalah kepercayaan positif atau negatif untuk menampilkan suatu perilaku tertentu. Kepercayaan atau beliefs ini disebut dengan behavioral beliefs. Seorang individu akan berniat untuk menampilkan suatu perilaku tertentu ketika ia menilainya secara positif. Sikap ditentukan oleh kepercayaan-kepercayaan individu mengenai konsekuensi dari menampilkan suatu perilaku (behavioral beliefs), ditimbang berdasarkan hasil evaluasi terhadap konsekuensinya (outcome evaluation). Sikap tersebut dipercaya memiliki pengaruh langsung terhadap intensi berperilaku, dan dihubungkan dengan norma subjektif, dan perceived behavioral control.

Model TRA/TPB mengkuantifikasi konsekuensi dengan mengalikan kemungkinan subjektif bahwa konsekuensi tersebut akan terjadi jika perilaku dilaksanakan dengan evaluasi mengenai konsekuensi tersebut (evaluation of that consequence). Hasil perkalian ini dijumlahkan untuk sejumlah konsekuensi yang mungkin.

Norma subyektif /subjective norm (SN) dari perilaku, adalah persepsi seseorang mengenai tekanan sosial untuk melakukan atau tidak melakukan perilaku (Ajzen,1988). Norma subjektif, juga diasumsikan sebagai suatu fungsi dari beliefs yang secara spesifik seseorang setuju atau tidak setuju untuk menampilkan suatu perilaku. Kepercayaan-kepercayaan yang termasuk dalam norma-norma subjektif disebut juga kepercayaan normatif (normative beliefs). Seorang individu akan berniat menampilkan suatu perilaku tertentu jika ia mempersepsi bahwa orangorang lain yang penting berfikir bahwa ia seharusnya melakukan hal itu. Orang lain yang penting tersebut bisa pasangan, sahabat, dokter, dsb. Hal ini diketahui dengan cara menanyai responden untuk menilai apakah orang-orang lain yang penting cenderung akan setuju atau tidak setuju jika ia menampilkan perilaku yang dimaksud.

Dalam model TRA/TPB, norma subjektif adalah fungsi dari normative beliefs, yang mewakili persepsi mengenai preferensi signficant others mengenai apakah perilaku tersebut harus 
dilakukan. Model ini mengkuantifikasi beliefs ini dengan mengalikan kemungkinan subjektif seorang significant other (disebut referent) berpikir bahwa seseorang harus melaksanakan perilaku tersebut dengan motivasi seseorang untuk mengikuti (motivation to comply) apa yang ingin dilakukan oleh referent.

Meskipun teori ini berangkat dari kajian psikologi sosial, dan dilahirkan oleh profesor di bidang psikologi sosial, tetapi aplikasi teori ini telah merambah ke banyak bidang kajian, seperti kesehatan, dan olah raga (Godin dkk., 1992; Billari \& Philipov, 2005; Higgins \& Marcum, 2005; Kouthouris \& Spontis, 2005), pendidikan (Okun \& Sloane, 2002; Martin \& Kullina, 2004; Marrone, 2005), marketing (Chiou, 1998), organizational behavior (Kolvereid, 1996; Wiethoff, 2004; Lanigan \& Bentley, 2006), dan lain lain.

Penelitian, dan pembahasan mengenai teori ini juga telah banyak dilakukan sejak mulai dipublikasikan oleh penggagasnya, bahkan oleh penggagasnya sendiri. Misalnya di tahun 1986 Ajzen bersama Madden meneliti tentang bagaimana memprediksi perilaku yang terarah ke pencapaian tujuan melalui komponen-komponen TPB. Di tahun 1991 Ajzen bersama Driver meneliti tentang bagaimana memprediksi keikutsertaan dalam kegiatan wisata melalui beliefs. Ajzen, dan Fishbein masih terus melakukan penelitian-penelitian, dan kajian-kajian bahkan hingga di tahun 2000-an untuk terus menyempurnakan teori mereka.

Ada beberapa tujuan, dan manfaat dari teori ini, antara lain adalah untuk meramalkan, dan memahami pengaruh-pengaruh motivasional terhadap perilaku yang bukan dibawah kendali atau kemauan individu sendiri. Untuk mengidentifikasi bagaimana, dan kemana mengarahkan strategi-strategi untuk perubahan perilaku, dan juga untuk menjelaskan pada tiap aspek penting beberapa perilaku manusia seperti mengapa seseorang membeli mobil baru, memilih seorang calon pemimpin dalam pemilu, mengapa tidak masuk kerja atau mengapa melakukan hubungan pranikah, dan lain sebagainya. Teori ini juga menyediakan suatu kerangka berpikir untuk mempelajari sikap terhadap perilaku.

Berdasarkan TPB, penentu terpenting perilaku seseorang adalah intensi untuk berperilaku. Intensi individu untuk menampilkan suatu perilaku adalah kombinasi dari sikap untuk menampilkan perilaku tersebut, dan norma subjektif. Sikap individu terhadap perilaku meliputi kepercayaan mengenai suatu perilaku, evaluasi terhadap hasil perilaku, norma subjektif, kepercayaan normative, dan motivasi untuk patuh.

Jika seseorang mempersepsi bahwa hasil dari menampilkan suatu perilaku tersebut positif, ia akan memiliki sikap positif terhadap perilaku tersebut. Demikan juga sebaliknya, jika suatu 
perilaku dipikirkan negatif maka ia akan memiliki sikap negatif terhadap perilaku tersebut. Jika orang-orang lain yang relevan memandang bahwa menampilkan perilaku tersebut sebagai sesuatu yang positif, dan seseorang tersebut termotivasi untuk memenuhi harapan orangorang lain yang relevan, maka itulah yang disebut dengan norma subjektif yang positif. Jika orang-orang lain melihat perilaku yang akan ditampilkan sebagai sesuatu yang negatif, dan seseorang tersebut ingin memenuhi harapan orang-orang lain tersebut, itu yang disebut dengan norma subjektif negatif. Sikap, dan norma subjektif diukur dengan skala (misalnya skala Likert) menggunakan frase suka/tidak suka, baik/buruk, dan setuju/tidak setuju. Intensi untuk menampilkan suatu perilaku tergantung pada hasil pengukuran sikap, dan norma subjektif. Hasil yang positif mengindikasikan intensi berperilaku. Menurut Eagly dan Chaiken (1993), pada TRA penggunaannya dibatasi pada kelompok perilaku yang bisa dikatakan volitional atau voluntary, yaitu perilaku yang dilaksanakan seseorang karena dia memutuskan untuk melaksanakannya. Pembatasan ini memiliki konsekuensi karena perilaku yang membutuhkan keterampilan, sumber daya, dan kesempatan yang tidak tersedia bukan perilaku yang volitional sepenuhnya. Teori ini juga memilih untuk tidak memberi ruang pada kemungkinan bahwa sikap kadang-kadang menimbulkan perilaku yang tidak melibatkan pikiran. Perilaku seperti itu bisa saja terjadi, misalnya kebencian terhadap kelompok, ras, atau etnis menimbulkan kekerasan yang tiba-tiba, dan spontan, atau kesukaan pada produk tertentu menimbulkan perilaku yang dikenal sebagai impulse buying. Pada teori ini dibatasi modelnya pada perilaku volitional, sehingga tidak menyertakan perilaku yang mungkin timbul, dan bebas dari sikap karena sudah merupakan kebiasaan seperti menggunakan sabuk pengaman.

Fishbein dan Ajzen menyatakan bahwa intensi berkorelasi dengan perilaku, dengan syarat keduanya diukur pada tingkat spesifisitas yang sama, dan interval waktu antara pengukuran intensi, dan perilaku cukup dekat. Randall dan Wolff (1994) melakukan meta-analisis kepada 98 penelitian untuk menguji hubungan antara intensi, dan perilaku berkaitan dengan interval waktu.

Berbeda dengan Fishbein dan Ajzen, Randall dan Wolff menemukan bahwa hubungan intensi dengan perilaku tetap kuat walaupun interval prediksinya mencapai 15 tahun. Korelasi intensi, dan perilaku tidak menurun secara signifikan dengan berjalannya waktu.

Dalam TRA, dan TPB, sikap yang diperhitungkan adalah sikap terhadap perilaku, bukan sikap terhadap target. Sikap terhadap perilaku masuk ke dalam model sebagai salah satu variabel yang mempengaruhi intensi. Variabel lain yang mempengaruhi intensi adalah norma subjektif. 
Ada satu variabel yang mempengaruhi intensi, dan terdapat dalam TPB namun tidak terdapat pada TRA yaitu PBC. Model ini dapat dinyatakan secara matematis sebagai berikut:

\section{$B \approx I=w 1 A T B+w 2 S N+w 3 P B C \ldots(2.12)$}

yang mana :

B adalah perilaku (behavior),

I adalah intensi (behavioral intention),

ATB adalah sikap terhadap perilaku (attitude toaward behaviour),

SN adalah norma subjektif (subjective norm),

PBC adalah perceived behavioral control, dan

w adalah bobot yang mengindikasikan pentingnya variabel-variabel tersebut secara relatif.

TRA (Gambar 2.1) paling berhasil ketika diaplikasikan pada perilaku yang di bawah kendali individu sendiri. Jika perilaku tersebut tidak sepenuhnya di bawah kendali atau kemauan individu, meskipun ia sangat termotivasi oleh sikap ,dan norma subjektifnya, ia mungkin tidak akan secara nyata menampilkan perilaku tersebut.

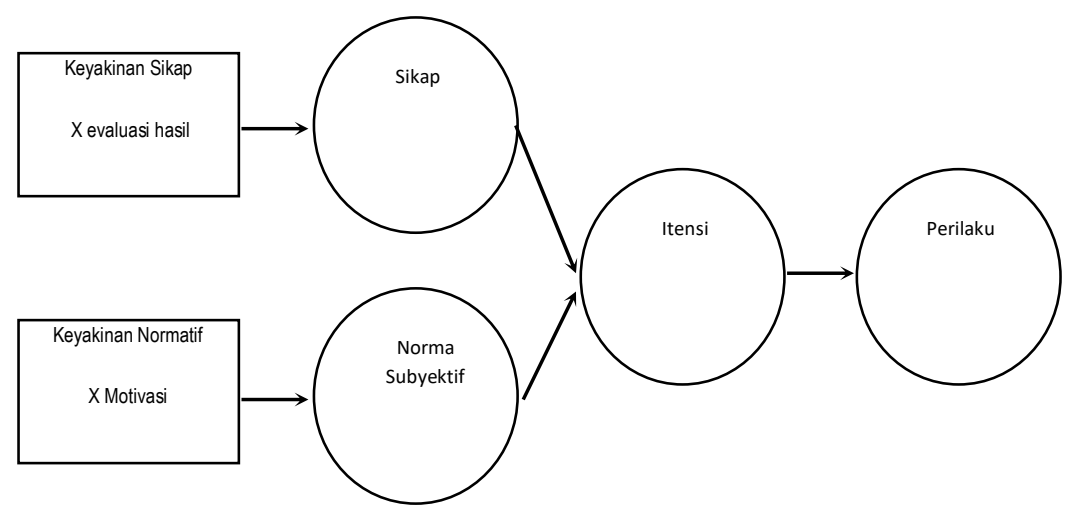

Sumber : Fishbein, M., Ajzen, I. (1975)

Gambar 2.1 Model Theory of Reasoned Action

Sebaliknya, TPB dikembangkan untuk memprediksi perilaku-perilaku yang sepenuhnya tidak di bawah kendali individu. Perbedaan utama antara TRA, dan TPB adalah tambahan penentu intensi berperilaku yang ke tiga, yaitu PBC, lihat Gambar 2.2. PBC ditentukan oleh dua faktor yaitu control beliefs, keyakinan mengenai kemampuan untuk mengendalikan, dan perceived power, persepsi mengenai kekuasaan yang dimiliki untuk melakukan suatu perilaku. PBC mengindikasikan bahwa motivasi seseorang dipengaruhi oleh bagaimana ia mempersepsi tingkat kesulitan atau kemudahan untuk menampilkan suatu perilaku tertentu. Jika seseorang memiliki control beliefs yang kuat mengenai faktor-faktor yang ada yang akan memfasilitasi suatu perilaku, maka seseorang tersebut memiliki persepsi yang tinggi untuk mampu 
mengendalikan suatu perilaku. Sebaliknya, seseorang tersebut akan memiliki persepsi yang rendah dalam mengendalikan suatu perilaku jika ia memiliki control beliefs yang kuat mengenai faktor-faktor yang menghambat perilaku. Persepsi ini dapat mencerminkan pengalaman masa lalu, antisipasi terhadap situasi yang akan datang, dan sikap terhadap norma-norma yang berpengaruh di sekitar individu.

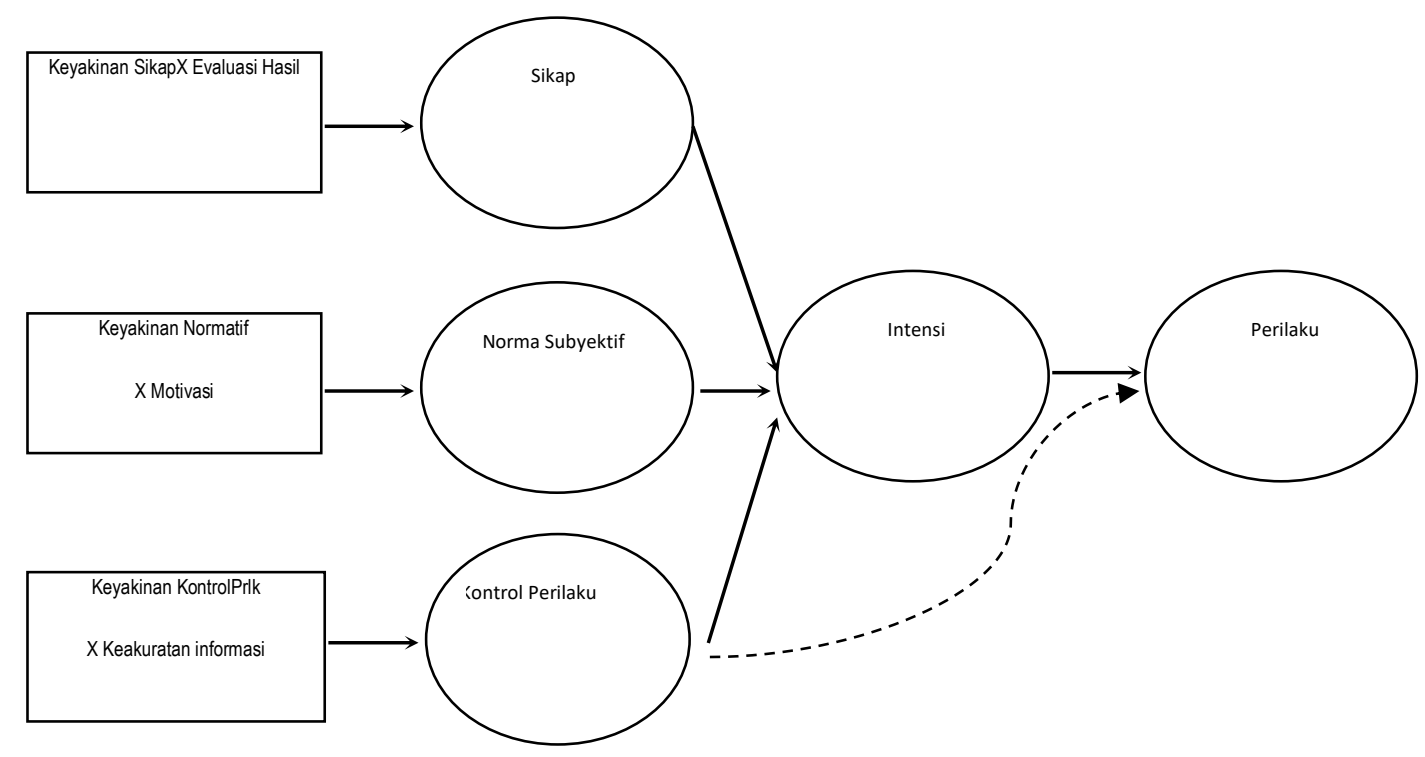

Sumber : Ajzen, I., (1991)

Gambar 2.2 Model Theory of Planned Behavior

TPB didasarkan pada asumsi bahwa manusia adalah makhluk yang rasional, dan menggunakan informasi-informasi yang mungkin baginya, secara sistematis. Orang memikirkan implikasi dari tindakan mereka sebelum mereka memutuskan untuk melakukan atau tidak melakukan perilaku-perilaku tertentu. Masalah terkait TRA akan muncul jika teori tersebut diaplikasikan pada perilaku yang tidak sepenuhnya di bawah kendali seorang individu tersebut. Untuk mengatasi keterbatasan tersebut, Ajzen memodifikasi TRA dengan mengikutsertakan variabel intensi yang ke tiga yang disebut perceived behavioral control (PBC). Dengan tambahan variabel ke tiga tersebut, ia menamai ulang teorinya menjadi Theory of Planned Behavior (TPB). PBC menunjuk suatu derajat dimana seorang individu merasa bahwa tampil atau tidaknya suatu perilaku yang dimaksud adalah di bawah pengendaliannya. Orang cenderung tidak akan membentuk suatu intensi yang kuat untuk menampilkan suatu perilaku tertentu jika ia percaya bahwa ia tidak memiliki sumber atau kesempatan untuk melakukannya meskipun ia memiliki sikap yang positif, dan ia percaya bahwa orang-orang lain yang penting baginya akan menyetujuinya. PBC dapat mempengaruhi perilaku secara langsung atau tidak langsung melalui intensi. Jalur langsung dari PBC ke perilaku diharapkan 
muncul ketika terdapat keselarasan antara persepsi mengenai kendali , dan kendali yang aktual dari seseorang atas suatu perilaku.

Kontrol perilaku yang dirasakan/ perceived behavioral control (PBC), adalah persepsi mengenai kemudahan atau kesulitan dalam melakukan perilaku, dan diasumsikan merefleksikan pengalaman di masa lalu dan antisipasi mengenai halangan (Ajzen, 1988). PBC adalah fungsi dari control beliefs, yaitu beliefs mengenai adanya faktor-faktor yang mempermudah atau mempersulit dilaksanakannya suatu perilaku, dan persepsi mengenai kekuatan faktor-faktor tersebut. Model theory of planned behavior mengkuantifikasi control beliefs dengan mengalikan kemungkinan subjektif adanya faktor-faktor yang mempersulit atau mempermudah dilaksanakannya suatu perilaku (strength of control belief atau control belief strength) dengan seberapa jauh adanya faktor tersebut memiliki kekuatan untuk mempermudah atau mempersulit pelaksanaan perilaku (power of control belief atau control belief power). Hasil perkalian ini dijumlahkan sesuai dengan jumlah control beliefs yang ada.

\section{PEMBAHASAN}

Studi tentang perhitungan VRS dengan pendekatan WTP metode stated preference (SP) lebih dominan digunakan dibanding metode reaveled preference (RP), karena metode SP memiliki kelebihan dibanding metode RP. Salah satu kelebihannya adalah metode SP lebih fleksibel dalam menilai keselamatan transportasi jalan (Andersson dan Lindberg, 2009; Hultkrantz, Lindberg, dan Andersson, 2006; Johannesson, Johansson, dan O'Connor, 1996). Apabila pendekatan WTP dengan metode RP hanya dapat digunakan untuk menilai WTP individu, dan keluarga secara terpisah, berbeda dengan pendekatan WTP dengan metode SP yang mampu menilai WTP keduanya secara bersamaan, selain itu penilaian dengan metode SP bisa mencakup penilaian altutristic responden (Bergstrom, 1982; Andersson dan Linberg, 2009; Jones Lee, 1991).

Dari uraian mengenai model utilitas deterministk terlihat bahwa model tersebut mengandalkan pada keakuratan dalam melakukan penilaian terhadap utilitas yang dirasakan individu terhadap alternatif-alternatif pilihan. Dalam pemilihan alternatif, penilaian terhadap utilitas biasanya didasarkan pada hal yang teramati, sedangkan faktor-faktor yang tidak teramati tidak dapat diukur secara matrik yang dinyatakan sebagai variabel acak. Penilian terhadap utilitas yang teramati tersebut dilakukan bukan dari sudut pandang konsumen secara internal tetapi dari sudut pandang peneliti yang menempatkan dirinya sebagai konsumen yang ditelitinya dengan mencoba untuk menilai utilitas yang dirasakan konsumen berdasarkan informasi yang dimiliki peneliti mengenai atribut-atribut yang ada pada alternatif 
tanpa berinteraksi secara langsung dengan konsumen yang ditelitinya. Joshi (2003) mendeskripsikan penilaian utilitas ini sebagai penilaian yang berdasarkan "intuisi" dari peneliti.

Untuk dapat memahami perilaku individu secara baik, dan benar, khususnya perilaku memilih diperlukan suatu pendekatan pemahaman yang berorentasi pada faktor internal individu yang mencakup persepsi maupun sikap individu terhadap serangkaian alternatif yang ada. Sikap merupakan konsep paling penting dalam memahami perilaku konsumen, sedangkan persepsi memegang peranan penting dalam pemasaran suatu produk karena akan mempengaruhi perilaku individu dalam menetapkan pilihannya (Simamora, 2004). Sikap, dan persepsi seseorang dalam perilaku memilih ini hanya dapat dipahami dengan melakukan pendekatan dari perspektif psikologi.

Metode SP menurut beberapa peneliti sangatlah kontroversial, dan mendapatkan banyak kritik, karena diyakini metode ini belum dapat menetapkan preferensi responden dengan tepat, dan masih banyak menimbulkan bias (Desvouges dkk., 1993; Diamond dan Hausman, 1994; Kahneman dkk., 1999). Menurut Kahneman dkk. (1999 : 204), jawaban responden terhadap pertanyaan pada survei SP lebih merefleksikan sikapnya ketimbang preferensinya. Selain itu bias yang terjadi pada survei SP juga disebabkan karena desain pertanyaan yang tidak tepat (Smith, 1992; Carson dan Mitchell, 1995). Metode SP yang dibangun atas dasar model utilitas deterministik, digunakan untuk mengetahui perilaku responden. Pada model tersebut dijelaskan bahwa fungsi utilitas pembentuk preferensi sifatnya koheren, dan invariant (Arrow dkk., 1996). Pada kenyataannya asumsi ini telah diuji, dan ditolak dalam berbagai penelitian yang dilakukan di bidang psikologi. Menurut Fuji dan Garling (2002 : 390), jika diasumsikan fungsi utilitas pembentuk preferensi sifatnya koheren, dan invariant, mestinya serangkaian alternatif preferensi responden yang dibangun pada kondisi hipotetis adalah sama dengan serangkaian alternatif preferensi responden pada kondisi sebenarnya. Pada kenyataannya ditemukan bukti lain, karena serangkaian alternatif preferensi responden tersebut tergantung pada konteks (Dawes, 1998; McFadden, 1999). Kemudian jika asumsi itu benar, mestinya respon setiap responden dalam menaggapi serangkaian alternatif preferensi yang sama tidak berbeda (Kahneman dkk., 1991; Keuhberger, 1998; Tversky dan Kahneman, 1981). Pada kenyataannya respon setiap responden ketika dihadapkan pada serangkaian alternatif pilihan preferensi yang sama persepsinya bisa berbeda-beda, tergantung kepada aspek rasionalitas masing-masing, dan kemampuan kognitifnya (Payne dkk., 1993). Berbagai konteks yang didokumentasikan dalam studi psikologi ini telah sering disebutkan sebagai bias atau anomali (Dawes, 1998; Kahneman dkk., 1991). Masih berkaitan dengan metode SP, menurut Fujii dan Garling (2002 : 391), pertanyaannya adalah : Apakah mungkin metode 
SP dapat mengetahui berbagai alternatif preferensi responden sebenarnya ? Beberapa Ahli Psikologi Kognitif (seperti : Fischhoff, 1991; Montgomery, 1983; Svenson, 1992, 1998), berpendapat bahwa preferensi manusia terbangun (are constructed), sehingga alternatif preferensi tersebut tergantung pada konteks yang membangunnya, atau dengan kata lain pilihan dari alternatif preferensi responden dapat diketahui setelah responden tersebut melakukan pilihannya. Pendapat ini dibenarkan oleh para peneliti lainnya (seperti : Ajzen dkk., 1996; Schkdane dan Payne, 1994; Slovic, 1995), dan menurut mereka banyak ditemui preferensi yang dirancang pada survei SP tidak dipahami oleh responden. Pertanyaan selanjutnya menurut Fujii dan Garling (2002 : 392) adalah : Sejauh mana preferensi yang dipilih responden pada survei SP akan merefleksikan perilaku sebenarnya? Menurutnya, ada dua alasan yang meragukan bahwa preferensi yang dipilih responden tidak merefleksikan perilakunya, yaitu : 1). Apakah preferensi yang dibangun pada kondisi hipotetis telah merefleksikan perilaku responden sebenarnya ? 2). Pada ilmu psikologi, variabel sikap lebih stabil digunakan untuk memprediksi perilaku (Eagly dan Chaiken, 1993). Dalam kaitannya dengan hal tersebut, variabel preferensi yang dipilih responden hanya dianggap sebagai bagian dari variabel sikap. Namun demikian, bukan artinya metode SP tidak bisa dipakai untuk memprediksi suatu perilaku. Untuk mengurangi bias yang terjadi, disarankan dalam merancang kuisioner survei SP lebih cermat (Baron, 1997; Mc Fadden, 1998, 1999; Smith 1992). Selain itu untuk mengurangi bias yang terjadi dapat digunakan metode statistik yang sesuai (Ben-Aktiva dan Morikawa, 1990; Morikawa, 1994; Morikawa dkk., 1991; Wardman, 1991). Berkaitan dengan variabel sikap, faktanya banyak juga ditemukan bukti empiris penelitian lainnya yang menjelaskan bahwa variabel sikap tidak bisa digunakan sebagai variabel yang akurat untuk memprediksi suatu perilaku (Fishbein dan Ajzen, 1975; Sheppard dkk., 1988). Bukti ini sesungguhnya hanya sebagian kecil temuan, masih banyak variabel lainnya yang mempengaruhi perilaku manusia selain sikap, seperti tekanan social (Asch, 1951; Fishbein dan Ajzen, 1975; Wood, 2000), norma personal, moralitas, dan kontrol terhadap perilaku (Ajzen, 1985, 1991). Ketidakmampuan variabel sikap untuk memprediksi perilaku secara akurat, karena adanya variabel lain yang mempengaruhi perilaku, merupakan alasan untuk menduga bahwa perilaku yang sebenarnya tidak semata-mata ditentukan oleh preferensi yang dipilih.

Suatu bagian terpenting dalam teori sikap adalah penjelasan tentang niat berperilaku/behavioral intention yang merupakan variabel prediksi terbaik untuk mengetahui perilaku, sebagaimana dijelaskan pada Theory of Reason Action (TRA) dari Fishbein dan Ajzen (1967) dan Theory planned behavior (TPB) dari Fishbein dan Ajzen (1988). Selanjutnya menurut Fujii dan Garling (2002 : 392), niat berperilaku sebenarnya adalah sebuah komitmen untuk bertindak, bukan hanya sekedar keinginan untuk bertindak. Terdapat perbedaan makna 
antara keduanya. Keinginan untuk bertindak merefleksikan preferensi responden untuk bertindak, sedangkan komitmen untuk bertindak merefleksikan kesanggupan responden untuk bertindak. Sebagai contoh komitmen responden untuk membantu responden lainnya tanpa harus memperdulikan biayanya adalah salah satu bentuk contoh perilaku yang tidak bisa dijelaskan oleh teori ekonomi mikro.

Meskipun niat berperilaku adalah variabel terbaik untuk memprediksi perilaku dibanding variabel lainnya, tetapi variabel ini juga tidak sempurna. Garling dkk. (1998), menjelaskan bahwa banyak berbagai macam faktor yang telah dibuktikan melalui kajian empiris yang mempengaruhi perilaku, sehinngga diyakini telah terjadi inkonsistensi dari niat berperilaku untuk memprediksi perilaku. Misalnya responden bisa jadi telah menyatakan niatnya atas suatu perilaku yang dikondisikan, tetapi pada kenyataannya responden tersebut tidak berperilaku sesuai niatnya (diistilahkan olehnya sebagai suatu kesalahan karena pelaksanaan/an error of commission), atau responden bisa jadi tidak menyatakan niatnya atas suatu perilaku yang dikondisikan, tetapi pada kenyataannya responden tersebut berperilaku sesuai perilaku yang dikondisikan (diistilahkan olehnya sebagai suatu kesalahan karena kelalaian /an error of omission). Penyebab utama dari kesalahan karena kelalaian /an error of omission adalah karena kebiasaan yang tidak dapat terkontrol oleh niat (Oullete dan Wood, 1998; Ronis et al., 1989; Verplanken dan Aarts, 1999). Penyebab lainnya yang menyebabkan inkonsistensi dari niat adalah perilaku responden yang berubah-ubah (Fishbein dan Ajzen, 1975).

Dari seluruh penjelasan di atas, diyakini bahwa metode SP yang digunakan untuk penetapan nilai preferensi/WTP berkeselamatan yang dibangun atas dasar teori perilaku dari prespektif ilmu mikro ekonomi saat ini belum optimal. Hal ini disebabkan karena belum ada instrumen yang mengontrol tentang kesesuaian peryataaan/jawaban responden tentang kesediaannya membayar biaya keselamatan terhadap perilakunya . Di sisi lain dari prespektif ilmu psikologi, niat berperilaku/intensi diyakini sebagai variabel terbaik untuk memprediksi perilaku. Oleh karena itu untuk mengontrol nilai preferensi/WTP berkeselamatan tersebut, perlu dikembangkan suatu alternatif kerangka pemikiran baru (inovasi), dengan cara mengikutsertakan variabel intensi sebagai instrumen yang mengontrol penetapan nilai preferensi/WTP berkeselamatan terhadap perilakunya. Pada penelitian ini disebut sebagai intensi berkeselamatan. 


\section{KESIMPULAN}

Dalam kaitannya dengan penelitian ini, yang selanjutnya perlu dilakukan adalah mengikutsertakan intensi berkeselamatan pada model penetapan VRS dengan pendekatan WTP metode SP sebagai instrumen kontrol, dan menganalisis interaksi antara preferensi berkeselamatan dengan intensi berkeselamatan dalam menentukan perilaku membayar keselamatan.

\section{DAFTAR PUSTAKA}

Ajzen, I. and Madden, T.J. 1986. Prediction of Goal-Directed Behavior: Attitudes, Intentions, and Perceived Behavioral Control. Journal of Experimental Social Phsycology, 22, 453474.

Ajzen, I. 1988.Attitudes, Personality, and Behavior. Milton-Keynes, Engl and: Open University Press \& Chicago, II: Dorsey Press.

Ajzen, I., 1985. From Intentions to Actions: A Model of Planned Behavior. In: Kuhl, J., Beckmann, J. (Eds.), Action Control: From Cognition to Behavior. Springer, Heidelberg, Pp. 11-39.

Ajzen, I., 1991. The Model of Planned Behavior. Organizational Behavior and Human Decision Processes 50, 179-211.

Ajzen, I., Brown, T.C., Rosenthal, L.H., 1996. Information Bi as In Contingent Valuation: Effects of Personal Relevance, Quality of Information, and Motivation. Journal of Environmental Economics and Management 30, 43-57.

Andersson, H., and Lindberg, G., 2009. Benevolence and The Value of Road Safety. Accident Analysis and Prevention, 41(2), 286e293.

Andersson, H., 2005. The Value of Safety as Revealed In The Swedish Car Market: An Application of The Hedonic Pricing Approach. Journal of Risk and Uncertainty, 30(3), $211 \mathrm{e} 239$.

Andersson. H., 2013. Consistency In Preferences For Road Safety, Elsevier.

Andersson. H., 2013. Willingness to Pay For Road Safety and Estimates of The Risk of Death:Evidence From A Swedish Contingent Valuation Study, Elsevier.

Arrow, K. J., Colombat to, E., Perlman, M., Schmidt, C., 1996. The Rational Foundations of Economic Behaviour. Macmillan Press, London.

Asch, S., 1951. Effects of Group Pressure Upon The Modification and Dis tortion of Judgement. In: Guestzkow, M.H. (Ed.), Groups, Leadership and Men. Carnegie, Pittsburgh, Pp. 117-190.

Baron, J., 1997. Biases In The Qualitative Measurement of Values For Public Decisions. Psychological Bulletin 122, 72-88.

Ben-Akiva, M., Morikawa, T., 1990. Estimation of Switching Models From Revealed Preferences and Stated Intentions. Transportation Research 24a (6), 485-495.

Ben-Aktiva, M., and Lerman, S.R., 1985.Discrete Choice Analysis, Model and Aplication to Travel Dem and.

Billari, F.C., and Philipov, D. 2005. Attitudes, Subjective Norms and Perceived Behavioral Control as Predictors of Fertility Intentions, Prepared For Paa 2005.

Carson, R.T., Mitchell, R.C., 1995. Sequencing and Nesting In Contingent Valuation Surveys. Journal of Environmental Economics and Management 28, 155-173.

Chiou, Jyh-Shen., 1998. The Effects of Attitude, Subjective Norm, and Perceived Behavioral Control On Consumers' Purch ase Intentions: The Moderating Effects of Product 
Knowledge and Attention to Social Comparison Information. Proc Natl.Sci. Counc. Roc (C). Vol.9 No.2, 298-308

Dawes, R.M., 1998. Behavioral Decision Making and Judgment. In: Gilbert, D.T., Fiske, S.T., Lindzey, G. (Eds.), H andbook of Social Psychology, Fourth Ed. Mcgraw-Hill, Bos ton, Ma, Pp. 497-548.

Desvouges, W.H., Johnson, F.R., Dunford, R.W., Hudson, S.P., Wilson, K.N., 1993. Me asuring Natural Resource Damage With Contingent Valuation: A Test of Validity and Reliability. In: Contingent Valuation: A Critical assessment. North-Holl and, Amsterdam, Pp. 91-159.

Diamond, P.A., Hausman, J.A., 1994. Contingent Valuation: Is Some Number Better Than No Number? Journal of Economic Perspectives 8, 45-64.

Eagly, A.H., Chaiken, S., 1993. The Psychology of Attitudes. Harcourt Brace College Publishers, Fort Worth, Tx.

Fischh off, B., 1991. Value Elicitation: Is There Anything In There? American Psychologist 46, 837-847.

Fishbein, M., Ajzen, I., 1975. Belief, Attitude, Intention, and Behavior: An Introduction to Model and Research.

Fujii, S., Garling, T., 2002. Application of Attitude Model For Improved Predictive Accuracy of Stated Preference Methods In Travel Dem and Analysis, Transportation Research Part A 37(2003)389-402, Pergamon.

Godin, G., Valois, P., Lepage, L., \& Desharnais, R. (1992). Predic tors of Smoking Behaviour: An Application of Ajzen's Theory of Planned Behavior.British Journal of Addiction, 87, 1335-1343.

Higgins, G.E. and Marcum, C.D., 2005, Can The Theory of Planned Behavior Mediate The Effects of Low Self-Control On Alcohol Use?, College Student Journal, Vol. 39, Issue: 1.

Hultkrantz, L., Lindberg, G., and andersson, C. (2006). The Value of Improved Road Safety. Journal of Risk and Uncertainty, 32(2), 151e170.

Johannesson, M., Johansson, P.-O., and O'connor, R. M., 1996. The Value of Private.

Jones-Lee, M. W., 1974. The Value of Changes In The Probability of Death Or Injury. Journal of Political Economy, 82(4), 835e849.

Joshi, P.,M., 2003. R asoned Action Versus Planned Behaviour In Bus Use, Dissertation, The Ohio State University.

Kahneman, D., Knetsch, J.L., Thaler, R.H., 1991. Anomalies: The Endowment Effect, Loss Aversion and Status Quo Bi as. Journal of Economic Perspectives 5, 193-206.

Kahneman, D., Ri tov, I., Schkade, D., 1999. Economic Preferences Or Attitude Expressions.

Keuhberger, A., 1998. The Influence of Framing On Risky Decisions: A Meta-Analysis. Organizational Behavior and Human Decision Processes 75 (1), 23-55.

Kolvereid, L. 1996. "Prediction of Employment Status Choice Intentions" Entrepreneurship Theory and Practice. 21 (1), 47-57.

Koppelman. F. S. and Ch andra Bhat, 2006. A Self Instructing Course In Mode Choice Modeling: Multinomial and Nested Logit Models

Kouthouris, C.H. and Spontis, A., 2005, Outdoor Recreation Participation: An Application of The Theory of Planned Behavior., The Sport Journal, Vol. 8 No. 3, United States Sport Academy.

Lanigan, Mary L. and Bentley, Jennifer., 2006. Collecting Sophisticated Evaluations Even When Corporate Culture Is Resistant. Performance Improvement. Vol.45 No.1, 32-51

Marrone, Stephen Richard 2005. Attitudes, Subjective Norms and Perceived Behavioral Control: Critical Care Nurses Intentions to Provide Culturally Congruent Care to Arab Muslims. Research Report. Columbia University Teachers Colllege

Martin, J.J. and Kullina, P.H., 2004, Self-Efficacy Theory and Theory of Planned Behavior: Teaching Physically Active Physical Education Cl asses, Research Quarterly For Exercise and Sport, Vol. 75 No. 3, Pp. $288-297$

Mcfadden, D., 1998. Measuring Willingness- to-Pay For Transportation Improvement. In: G€Arling, T., Laitila, T., Westin, K. (Eds.), Theoretical Foundations of Travel Choice Modelling. Elsevier, Amsterdam, Pp. 251-279. 
Mcfadden, D., 1999. Rationality For Economists? Journal of Risk and Uncertainty 19, 73105.

Morikawa, T., 1994. Correcting State Dependence and Serial Correlation In The Rp/Sp Combined Estimation Method. Transportation 21 (2), 153-165.

Morikawa, T., Ben-Akiva, M., Yamada, K., 1991. Forec asting Intercity Rail Ridership Using Revealed Preference and Stated Preference Data. Transportation Research Record 1328, 30-35. Morikawa, T., Ben-Akiva, M., Mcfadden, D. Incorporating Psychometric Data In Econometric Travel Dem and Models. Journal of Econometrics, In Press.

Okun, Morris A. and Sloane, Erin S. (2002) Application of Planned Behavior Theory to Predicting Volunteer Enrollment By College Students In A Campus-B ased Program. Social Behavior and Personality. Tempe: Arizona State University

Payne, J.W., Bettman, J.R., Johnson, E.J., 1993. The Adaptive Decision Maker. Cambridge University Press, New York.

Pindyck, Robert, S., and andiel, L. Rubinfield, 2001.Microeconomics, New York : Prentice Hall.

Randall, D.M. \& Wolff, J. A. 1994. The Time Interval In The Intention-Behaviour Relationship: Meta-Analysis.Bristish Journal of Social Psychology, 33, 405-418.

Rosen, S. (1988). The Value of Changes In Life Expectancy. Journal of Risk and Uncertainty, 1(3), 285e304. Safety Versus The Value of Public Safety. Journal of Risk and Uncertainty, 13(3), 263e275.

Schkade, D.A., Payne, J.W., 1994. How People Respond to Contingent Valuation Questions: A Verbal Pro tocol Analysis of Willingness to Pay For An Environmental Regulation. Journal of Environmental Economics and Management 26, 88-109.

Simamora Henry, 2004. Manajemen Sumber Daya Manusia. Edisi Ke-3. Stie Ykpn. Yogyakarta.

Slovic, P., 1995. The Construction of Preferences. American Psychologist 50, 364-371.

Smith, V.K., 1992. Arbitrary Values, Good Causes, and Premature Verdicts. Journal of Environmental Economics and Management 22, 71-89.

Svenson, O., 1992. Differentiation and Consolidation Model of Human Decision Making: A Frame of Reference For The Study of Pre- and Post-Decision Process. Acta Psychologica 80, 143-168.

Svenson, O., 1998. The Perspective From Behavioral Decision Model On Modeling Travel Choice. In: G€Arling, T., Laitila, T., Westin, K. (Eds.), Theoretical Foundations of Travel Choice Modelling. Elsevier, Amsterdam, Pp. 141-172.

Tversky, A., Kahneman, D., 1981. The Framing of Decisions and The Psychology of Choice. Science 211, 453-458.

Wieth off, C. 2004, "Motivation to Learn and Diversity Training: Application of The Theory of Planned Behavioer, "Human Resource Development Quarterly, Vol.15, Pp. 263-278.

Wood, W., 2000. Attitude Change: Persu asion and Social Influence. Annual Review of Psychology 51, 539-570. 